\title{
Contribuição previdenciária: natureza jurídica
}

Sumário - A natureza jurídica da contribuição previndenciária. Classificação dos tributos. A estrutura lógica da norma tributária. A estrutura normativa das contribuições previdenciárias. Limitações constitucionais ao poder de tributar. O Decreto n. 83.081 , de 24 de janeiro de 1979 e a Lei $n^{\circ} 6.887$, de 10 de dezembro de 1980.

\section{A natureza juridica da contribuição previdenciária}

A doutrina mais recente identifica o tributo como norma jurídica geral, não autônoma, que estabelece uma prestação precuniária ao Estado, como resultante da ocorrência de fato lícito. (Veja-se a respeito: Paulo de Barros Carvalho, Teoria da norma tributária, Ediçðes Lael, São Paulo, 1974, p. 75 a 90; Marco Aurélio Greco, Norma jurídica tributária, Educ-Saraiva, São Paulo, 1974, p. 20 e seguintes; Américo Masset Lacombe, Obrigação Tributária, RT, São Paulo, 1977, p. 21 a 38, elmposto da importação, RT, São Paulo, 1979, p. 6a 10, ep. 109e 110.)

Paulo de Barros Carvalho (obra citada, p. 88) define tributo, em uma configuração estática, como sendo "a endonorma que apresenta como hipótese um conjunto de critérios para a identificação de fatos da realidade física, que não acordos de vontade considerados em si mesmos, e, como conseqüência, um conjunto de critérios que nos permite identificar uma relação jurídica que se instaura entre o Estado (por via de regra), na qualidade de sujeito ativo e alguma pessoa física ou jurídica, na condição de sujeito passivo, mediante a qual haverá o primeiro o direito subjetivo público de exigir da segunda o cumprimento de dever jurídico consubstanciado numa prestação pecuniária".

Ao definir tributo como endonorma (Paulo de Barros Carvalho) ou como norma geral não autônoma (os demais autores mencionados), a doutrina mais moderna - que neste aspecto não inovou fornece como elemento caracterizador do tributo o fato de não ser ele sanção de ato ilícito. Isto significa que o fato descrito na hipótese de incidência de uma norma tributária é fato lícito.

Toda vez, por conseguinte, que estivermos diante de uma obrigação de entregar dinheiro lou bem cujo valor nele se possa exprimir) ao Estado em decorrência da prática de fato lícito (que não seja acordo de vontade considerado em si mesmol, estaremos diante de obrigaçðes tributárias, isto é, de obrigação que nasceu, de modo mediato, da ocorrência de fato previsto hipoteticamente numa norma secundária, isto é, norma que não sanciona ato ilicito.

Mas, o direito positivo brasileiro definiu tributo, no art. 3. do Código Tributário Nacional, e, se bem que tal definição não seja cientificamente feliz, tem a autoridade do direito posto, estando assim redigida: "Tributo é toda prestação pecuniária compulsória, em moeda ou cujo valor nela se possa exprimir, que não constitua sanção de ato ilícito, instituída em lei e cobrada mediante atividade administrativa plenamente vinculada".

Ora, a contribuição previdenciária é uma prestação pecuniária compulsória, em moeda, não 
constitui sanção de ato ilícito, só pode ser instituída por lei, e é cobrada mediante atividade administrativa plenamente vinculada. Vale recordar a lição de Geraldo Ataliba (parecer in Revista dos Tribunais 402/43) que se reporta, por sua vez, a vários insignes mestres do nosso direito tributário:

"Toda e qualquer discussão sobre a natureza tributária da 'contribuição' previdenciária perdeu o sentido, com a promulgação - quinze dias após a publicação do Código Tributário Nacional - do Decreto-Lei n. 27, de 14 de novembro de 1966, que veio dispor expressamente (embora isto fosse totalmente despiciendo) que o Código não excluía a incidência e a exigibilidade "V. das contribuições enumeradas no $\S 22^{\circ}$, do art. 34 da Lei n. 4.863..." , isto é, da própria chamada contribuição previdenciária.

Isto significa que, além das razões doutrinárias já expostas, ex vi legis esta exação é tributo para todos os efeitos.

Essa inteligência da questão já era administrativamente adotada, uma vez que constante do Regulamento Geral da Previdência Social (Decreto n? 72.771, de 1973), no art. 333 e seu parágrafo único.

Esta posição sempre a adotamos, expondo-a expressamente (Sistema constitucional tributário brasileiro, p. 185 e segs., e Hipótese de incidência tributária, p. 199 a 201). Dela não discrepa Contreiras de Carvalho, no seu Doutrina e aplicação do direito tributário (p. 149 a 151). Idêntico é o pensamento de Baleeiro (Introdução, ed. 1968, p. 287, Direito tributário brasileiro, 6 ed. p. 568 e segs., e Limitacões constitucionais ao poder de tributar, 2 ed. , p. 253 a 256). O insigne tributarista gaúcho Alfredo A. Becker (Teoria geral do direito tributário) é incisivo, ao escrever: "A doutrina tem demonstrado que as contribuiçðes parafiscais ...são simples impostos com destinação determinada e(ou) ...verdadeiras taxas" (p. 349)

Fanuchi conclui da mesma forma (Curso... p. 31), seguindo a orientação do mestre Gomes de Sousa (Compêndio, ed. 1954, p. 131).

Recentissimamente, Marco Aurelio Greco reelabora toda a construção dogmática fundamental do feito tributário (Norma jurídica tributária) chegando a mesma conclusão (p. 43).

Não vamos cansar o leitor multiplicando citações e indicações bibliográficas dos nossos mais variados escritores, para reafirmar e robustecer aquilo que é pacífico, tranqüilo e indiscutível, como a inquestionável natureza tributária da chamada contribuição previdenciária.

Consagrando a conclusão unânime da doutrina, a Emenda Constitucional n. ${ }^{\circ}$, de 17 de outubro de 1969, referiu-se à contribuição previdenciária como tributo, dispondo sobre ela no $\S 2^{\circ}$. , item I, do art. 21 (que enumera os impostos federais), colocado dentro do capítulo V (Sistema Tributário) no Título I (Da Organização Nacional). Assim, após enumerar, no artigo 21, os impostos de competência da União, e, no $\S 1 \%$, do mesmo artigo, estabelecer a competência residual, dispunha o $\S 2$. .

$\S 2^{\circ}$ - A União pode instituir: contribuições, observada a faculdade prevista no item I deste artigo, tendo em vista intervenção no domínio econômico e o interesse da previdência social ou de categorias profissionais;

É certo que a Emenda Constitucional n. ${ }^{\circ}$, de 14 de abril de 1977, deu nova redação ao item acima transcrito, substituindo a expressão "interesse da previdência social" pela sentença "para atender diretamente à parte da União no custeio dos encargos da previdência social" . A referência à contribuição previdenciária foi transferida para o item X, do artigo 43, que fixa a competência do Poder Legislativo. No entanto, qualquer analista que pretender estudar a natureza jurídica da contribuição social, referida no último artigo, chegará à inexorável conclusão de que se trata da mesma contribuição previdenciária, referida anteriormente, e que possui natureza de tributo. Além do mais, não é o fato de estar colocado dentro do capítulo referente ao Sistema Tributário que dá a natureza tributária a qualquer obrigação. 0 capítulo da Constituição referente ao Sistema Tributário não trata apenas de matéria tributária, pois ali encontramos disposiç̃es sobre as receitas do imposto de importação e do imposto sobre operações financeiras, afirmando que a lei deverá destinar tais receitas à formação de reservas monetárias ou de capital para financiamento de programa de desenvolvimento econômico ( $\S 4^{\circ}{ }^{\circ}$, do art. 21). Também aí encontramos a disposição do $\S 1$. , do art. 23 , que determina que o produto da arrecadação do imposto de renda incidente sobre rendimentos do trabalho e de títulos da divida pública pagos pelos Estados e pelo Distrito Federal, será distribuído a estes, na forma que a lei estabelecer, quando tais entes públicos forem obrigados a reter o tributo. E ainda o disposto no art. $23, \S 8{ }^{\circ}$, que diz que, do produto de arrecadação do imposto sobre operações relativas à circulação de mercadorias, oitenta por cento constituirão receita dos Estados e, vinte por cento, dos Municipios, afirmando ainda que as parcelas pertencentes aos Municipios serão creditadas em contas especiais, abertas em estabelecimentos oficiais de crédito na forma e nos prazos fixados em lei federal. Podemos ainda trazer à colocação o $₹ 1^{\circ}$, do art. 24, que dá aos Municípios o produto da arrecadação do imposto sobre a propriedade territorial rural, incidente sobre os imóveis situados em seu território, 
havendo ainda disposição determinando a distribuição aos Municípios, na forma da lei, do produto da arrecadação do imposto sobre a renda, incidente sobre rendimentos do trabalho e dos títulos da dívida pública por ele pagos, quando forem obrigados a reter o tributo (art. $24, \S 2^{\circ}$.). E o que dizer dos arts. $25 \mathrm{e}$ 26 , também colocados dentro do capítulo referente ao Sistema Tributário e que determinam modos de distribuição do produto da arrecadação do imposto de renda e IPI (art. 25) e do imposto único (art. 26, I a III e § 1.)? Todas estas disposições regulam a destinação do produto da arrecadação do tributo, lógica e cronologicamente posterior à instituição do tributo. Podemos aqui repetir as palavras de José Souto Maior Borges (Parecer sobre a constitucionalidade do empréstimo compulsório instituído pelos Decretos-Leis n:s 1.782/80 e 1.790/80, Separata da Revista Vox Legis, 140/61): "Todos esses dispositivos contemplam a destinação constitucional do tributo, ou seja, regulam um componente normativo que se pretende estranho à instituição do tributo. Algo que, num sentido figurado e metafórico, poder-se-ia considerar externo ao âmbito material das normas tributárias. E assim o será porque o tributo, ensina-o tradicionalmente a doutrina, é uma categoria normativa que tem o seu ciclo vital instaurado com o surgimento do fato jurídico tributário (fato gerador, C.T.N. art. 114) e se extingue com o pagamento ou outro modo de extinção das obrigações tributárias legalmente previsto (C.T.N., art. 156, I a X). Portanto, uma vez efetuado o pagamento, extinguir-se-ia o tributo devido É precisamente nesse sentido que Se afirma ser a aplicação, ou melhor, a destinação que se der ao quantum da prestação tributária, algo estranho ou externo ao tributo e pois tributariamente indiferente. A matéria estaria submetida, já então, ao direito financeiro e não ao direito tributário..."

Mas, se é certo que o capítulo da Constituição referente ao Sistema Tributário não trata apenas de normas tributárias, ou de aspectos de normas tributárias, como vimos acima, menos certo não é que tal capítulo não esgota as regras atinentes aos tributos. Vejamos os exemplos. O art. 43 , que enumera as atribuições do Poder Legislativo, afirma caber "ao Congresso Nacional, com a sanção do Presidente da República, dispor sobre todas as matérias de competência da União, especialmente: I - tributos, arrecadação e distribuição de rendas". . Este artigo reafirma o princípio da legalidade dos tributos, estabelecido no art. 19, I, e novamente reafirmado no $\S$ 29 , do art. 153. O art. 55, que dispõe sobre a possibilidade da utilização do decreto-lei, em casos de urgência e interesse público relevante, salienta, no inciso II, a possibilidade de sua utilização para veicular normas tributárias. E o que dizer do salário-educação, genuíno imposto, referido no art. 178 , incluído no Título IV , concernente à Família, Educação e Cul- tura? Portanto, o fato de a Emenda Constitucional $n .^{\circ} 8$, de 14 de abril de 1977 , ter retirado do $\S 2^{\circ}$, item I, do art. 21 e deslocado para o art. 43 (Atribuições do Poder Legislativol a referência às contribuições previdenciárias, em nada modifica a natureza jurídica destas contribuições. Eram e continuam sendo tributos, não em razão da sua colocação dentro do texto constitucional, mas em razão da própria estrutura normativa de tais contribuições.

"Qualquer exigência de dinheiro que faça o Estado aos sujeitos à sua soberania, somente pode configurar tributo, requisição ou confisco". Vejamos, em primeiro lugar, a possibilidade de se caracterizar a contribuição previdenciária como confisco ou como requisição, verificando, inclusive, se tem procedência a classificação acima, da lavra do professor Geraldo Ataliba lapud Carlos Mário Velloso, voto proferido, no Tribunal Federal de Recursos, no Incidente de Uniformização de Jurisprudência, na AC 58.664-SP). Em primeiro lugar, a classificação acima não mencionou a multa que, configurando sanção de ato ilícito, poderia ser de fato omitida se a referida classificação versasse apenas sobre as obrigações não sancionatórias, isto é, decorrentes da prática de atos lícitos. No entanto, no sistema jurídico constitucional brasileiro, confisco é pena, logo norma primária, sancionatória, que tem como hipótese de incidência a prática de ato ilícito. Isto está claro no $\S 1$. , do art. 153, da Constituição que afirma textualmente que "não haverá pena de morte, de prisão perpétua, de banimento, ou de confisco,..." Logo confisco é pena, é sanção, e isto afasta qualquer possibilidade de se classificar a contribuição previdenciária como confisco, será, por via de conseqüência, considerada inconstitucional, visto que o confisco é vedado. Assim, as obrigações de pagar o Estado decorrentes da prática de atos lícitos ou são tributos ou são requisições. Se decorrentes de atos ilícitos são multas, não se mencionando os confiscos por inconstitucionais. Apenas a título de esclarecimento, diremos que não se deve confundir confisco (sanção, norma primária) com tributo confiscatório (norma secundária, não sancionatória). No entanto, o qualificativo não tem qualquer conotação jurídica, pois a medida do tributo é matéria pré-jurídica, de interesse para a política fiscal, mas sem qualquer relevância para o direito tributário.

Vejamos se as contribuições para a previdência podem ser classificadas como requisições. Para Celso Antônio Bandeira de Mello (Elementos de direito administrativo, RT, São Paulo, 1980 , p. 212) requisição "é o ato pelo qual o Estado, em proveito de um interesse público, constitui alguém, de modo unilateral e auto-executório, na obrigação de prestar-Ihe um serviço ou ceder-Ihe transitoriamente o uso de uma coisa, obrigando-se a indenizar os pre- 
juízos que tal medida efetivamente acarretar ao obrigado." Para Hely Lopes Meirelles (Direito administrativo brasileiro, RT, São Paulo, 4 ed., 1976, p. 575), requisição é a utilização coativa de bens ou serviços paticulares, pelo Poder Público, por ato de execução imediata e direta da autoridade requisitante e indenização ulterior, para atendimento de necessidades coletivas urgentes e transitórias" . O fundamento constitucional da requisição é o $\$ 22$, do art. 153, que fixa como seu pressuposto o perigo público iminente. Sem este pressuposto, as requisições são ilegítimas. Hely Lopes Meirelles nota ainda que a requisição é ato "discricionário quanto ao objeto e oportunidade da medida" (p. 576). Renato Alessi (Instituciones de derecho administrativo, trad. espanhola de Buenaventura Pellisé Prats, Bosch, Barcelona, 1970, tomo II, p. 560) nota como pressuposto da requisição o caráter extraordinário e ocasional das necessidades que hão de ser satisfeitas. Alcides Jorge Costa (Natureza jurídica dos empréstimos compulsórios, Rev. Dir. Adm. 70/1) salienta a distinção entre empréstimo compulsório e requisição ao afirmar que esta é ato parcialmente discricionário, porque a autoridade administrativa requisita bens ou serviços, nọs termos fixados em lei, mas quando e se entende conveniente. Assim, enquanto os tributos são exigidos por ato administrativo plenamente vinculado (C.T.N. art. 3.), a requisição é cobrada mediante atividade administrativa discricionária. Vê-se, portanto, que as contribuições previdenciárias não podem ser confundidas com requisição. Não possuem o pressuposto do perigo público iminente, o caráter ocasional, urgente, e são exigidas através de atividade administrativa plenamente vinculada. Não sendo confisco ou requisição, as contribuições previdenciárias só podem ser entendidas como tributos.

Assim, não é a colocação em capítulos da Constituição que conferiráa determinada obrigação a natureza tributária. Tal é determinada pela análise sistemática da obrigação. Vejamos a que espécie tributária pertence a contribuição previdenciária.

\section{Classificação dos tributos}

A moderna doutrina brasileira aceita quase que unanimente a classificação formulada por Geraldo Ataliba, que divide os tributos em vinculadose não vinculados. Este autor preleciona com sabedoria (Hipótese de incidência tributária, RT, São Paulo, 1975, p. 140):

"Examinando-se e comparando-se todas as legislações existentes - quanto à hipótese de incidência - verificamos que, em todos os casos, o seu aspecto material, das duas uma: a. ou consiste numa atividade do poder público lou numa repercus- são desta), ou, pelo contrário; b. consiste num fato ou acontecimento inteiramente indiferente a qualquer atividade estatal.

Esta verificação permite classificar todos os tributos, pois - segundo o aspecto material de uma hipótese de incidência consista ou não no desempenho de uma atividade estatal - em tributos vinculados e tributos não vinculados.

É que esta averiguação enseja afirmar que no primeiro caso - o legislador vincula o nascimento da obrigação tributária ao desempenho de uma atividade estatal e - no segundo - não".

A primeira vez que Geraldo Ataliba tornou pública esta sua classificação foi em 1969, num trabaIho denominado Considerações em torno da teoria jurídica da taxa (in RDP 9/42). Sua classificação teve, em 1971, o apoio consagrador de Rubens Gomes de Sousa (Natureza tributária de contribuição para o F.G.T.S. in RDP 17/305), que assim a sintetizou: "Nesta linha de pensamento enquadra-se a opinião, que adoto, de Geraldo Ataliba (RDP, vol. 9/43), de que os tributos podem ser "vinculados" ou "não vinculados" em função da natureza do seu fato gerador, nome que se dá à situação material ou jurídica definida em lei como necessária e suficiente para gerar a obrigação de pagá-los (Código Tributário Nacional, lei n? 5.172, de 25 de outubro de 1966, art. 114).

\section{Assim, invertendo a ordem:}

a. o tributo é "não vinculado" quando o seu fato gerador independa de qualquer atividade específica do governo tributante em relação ao contribuinte: é o caso dos impostos (Código Tributário Nacional, art. 16); ao contrário,

b. o tributo é "vinculado" quando o seu fato gerador seja uma atividade específica do governo tributante, a qual por sua vez pode ser (i) diretamente relativa ao contribuinte, como o exercício do poder de polícia ou a prestação ou disponibilidade de um serviço; é o caso das taxas (Código Tributário Nacional, art. 77); ou pode ser (ii) apenas indiretamente relativa ao contribuinte: é o caso das contribuições (Código Tributário Nacional), arts. 81 e 217), como adiante veremos mais amplamente."

Verificada assim a classificação dos tributos, cumpre-nos examinar a composição normativa das chamadas contribuições previndenciárias. Empregamos propositadamente o plural para deixar claro, desde logo, que não existe apenas uma contribuição previdenciária. Existem tantas quantas forem as normas juridicas extraídas dos textos legais, e, para que se possa atender com precisão tal afirmativa, tornam-se necessárias algumas considerações sobre a estrutura lógica da norma jurídica. 


\section{A Estrutura lógica da norma tributária}

0 problema da estrutura lógica da norma jurídica tributária já foi amplamente abordado e discutido entre nós (Alfredo Augusto Becker, Teoria geral do direito tributário, Saraiva, São Paulo, 1972; Geraldo Ataliba, Hipótese de incidência tributária, RT, São Paulo, 1975; Paulo de Barros Carvalho, Teoria da norma tributária, Lael, São Paulo, 1974; Marco Aurélio Greco, Norma jurídica tributária, Educ-Saraiva, São Paulo, 1974; Américo Masset Lacombe, Obrigação tributária, RT, São Paulo, 1977 e Imposto de importação, RT, São Paulo, 1979), e todos os estudos reconhecem que a norma jurídica, qualquer que seja ela, tem a seguinte estrutura lógica: uma hipótese à qual se imputa uma conseqüência. Isto significa que a norma se exterioriza como um juízo hipotético. Mas as normas jurídicas são em si mesmas imperativas. Contêm um comando, uma ordem. Como a grande maioria delas exterioriza-se por meio lingüístico, a norma jurídica apresenta-se com a estrutura lógica de um juízo hipotético. Temos então de distinguir três realidades: a. a norma jurídica em si, que consiste num comando ou imperativo; b. a linguagem utilizada pelo legislador ao editar a norma, e que consiste numa formulação hipotética; c. a metalinguagem utilizada pelo cientista do direito ao descrever a norma que é a proposição jurídica, formulada como juízo hipotético.

A norma é assim a imputação de um conseqüente a um antecedente. Mas, se a normaé, em si, um comando, apenas formulada, em sua expressão lingüística como juízo hipotético, tal não ocorre com a proposição jurídica, a qual é, em si mesma, um juízo hipotético. Temos então que a norma jurídica apresenta-se, aos olhos do cientista de direito, sob roupagem lingüística que tem a forma de um juízo hipotético. Ao estudar a linguagem do legislador, o cientista formula, numa metalinguagem, a proposição jurídica, que é um juízo hipotético. A norma terá assim uma formulação deôntica, estabelece um dever-ser, o conseqüente.

Mas, se a norma jurídica é uma imputação de um conseqüente a um antecedente, o mesmo se pode dizer do tributo. Tributo é norma jurídica secundária, não autônoma, dependente da norma primária que estabelece a sanção. A sanção, estabelecida na norma primária, não é tributo, enemé objeto de estudo do direito tributário. Integra o direito administrativo.

Partindo da definição de tributo como norma jurídica secundária (veja-se inciso 2.1), não autôno$\mathrm{ma}$, e entendendo a norma jurídica como a imputação de um conseqüente a um antecedente, isto é, ocorrendo, no mundo fático, a circunstância hipoteticamente prevista no antecedente normativo, deve-ser o conseqüente, cumpre-nos estudar cada uma das partes da norma jurídica tributária, a saber, o antecedente (hipótese) e o conseqüente (mandamento). "Pertence, com efeito, à hipótese legal tudo aquilo que se refere à situação a que vai conexionado o dever-ser (Sollen), e à conseqüência jurídica aquilo que determina o conteúdo deste dever-ser" (Karl Engisch, Introdução ao pensamento jurídico, trad. de J. Baptista Machado, Fundacão Calouste Gulbenkian, Lisboa, 2 ed., 1968, p. 43). Estão, por conseguinte, na hipótese (antecedente) o critério material, o critério espacial e o critério temporal, e no mandamento (conseqüente, estatuição) o critério pessoal e o critério quantitativo, o qual engloba a base de cálculo e a alíquota (Paulo de Barros Carvalho, obra citada, p. 113 a 168). A hipótese legal (antecedente) será assim a previsão abstrata de um fato ou uma situação (auferir renda, industrializar produtos, ser proprietário de imóveis, importar mercadorias, etc.) - que denominamos núcleos, condicionados por coordenadas de tempo e espaço. O mandamento (conseqüente, estatuição) será a previsão, também abstrata, do conteúdo de uma relação jurídica, que se instaurará entre dois sujeitos, ocorrido o fato ou verificda a situação, previstos no hipótese, dentro das condicionantes de tempo elugar. Ocorrido, na realidade fenomênica, o fato imponível, hipotética e abstratamente previsto no antecedente normativo (hipótese de incidência), o conseqüente (mandamento, estatuição) incide, instaurando uma relação jurídica entre dois sujeitos, e fornecendo critérios para a determinação do seu conteúdo. Para a incidência do mandamento (conseqüente, estatuição), torna-se necessária a perfeita subsunção do fato à hipótese (antecedente), isto é a adequação do fato ocorrido à descrição prevista na hipótese normativa (antecedente). Verificada a subsunção, e só nesse caso, o mandamento incide, instaurando a relação jurídica tributária.

A norma jurídica tributária tem portanto a seguinte estrutura: um antecedente (hipótese de incidência) que se compõe de um núcleo, condicionado por coordenadas de espaço e tempo; um conseqüente (mandamento) que se compõe de aspectos quantitativos (alíquota e base de cálculo) e de aspectos pessoais (sujeito ativo e sujeito passivo). O que caracteriza qualquer tributo é, por conseguinte, a estrutura lógica da norma. Se estivermos diante de estruturas normativas diversas estaremos diante de tributos diversos, ainda que estas normas diversas estejam envolvidas pela mesma denominação jurídica e reguladas pelo mesmo diploma legal. No sistema jurídico pátrio podemos verificar inúmeros exemplos de tributos diversos, designados pelo mesmo nomem juris, e regulados pelas mesmas disposições legais. A legislação do I.P.I., por exemplo, consagra três impostos distintos. A lei n: 4.502, de 30 de novembro de 1964, já distinguia nitidamente 
dois impostos, quando definia o fato gerador, quanto aos produtos de procedência estrangeira, o respectivo desembaraço aduaneiro, e quanto aos de produção nacional, a saída do respectivo estabelecimento. O Código Tributário Nacional (lei n. 5.172, de 25 de outubro de 1966), no seu art. 46, estabelece que o I.P.I. tem como fato gerador: a. o seu desembaraço aduaneiro, quando de procedência estrangeira; b. a saída do estabelecimento do contribuinte; c. a sua arrematação quando apreendido, abandonado ou levado a leilão. Ora, como os núcleos das hipóteses de incidência são diversos, estamos diante de normas diversas, e, por via de conseqüência, de tributos diversos. E não é apenas o núcleo da hipótese de incidência que é diverso. As coordenadas específicas de espaço são diversas la aduana, no primeiro caso, o estabelecimento industrial, no segundo, e o local da arrematação, no terceiro). Os sujeitos passivos são diversos (o importador, o produtor e o arrematante). Temos assim três impostos distintos com a mesma denominação de imposto sobre produtos industrializados. E o que dizer então da legislação do imposto de renda, que sob o mesmo nomen juris estabelece uma série de impostos diversos? O imposto que incide sobre a renda líquida das pessoas físicas não é o mesmo que incide sobre o lucro real das pessoas jurídicas, este, por sua vez, distingue-se do imposto incidente sobre os lucros e reservas excedentes ao capital social das companhias. O imposto suplementar incidente sobre o montante dos lucros e dividendos líquidos efetivamente remetidos a pessoas físicas e juridicas, residentes ou com sede no exterior sempre que a média das remessas, em um triênio, exceder a $12 \%$ do capital e reinvestimentos registrados no Banco Central, não é o mesmo que incide sobre a renda líquida das pessoas físicas ou lucro real das pessoas jurídicas. Demos estes exemplos apenas para demonstrar que tembém sob a denominação de contribuição previdenciária, podemos encontrar diversas estruturas normativas, o que significará a existência de diversos tributos.

\section{A Estrutura normativa das contribuições previdenciárias}

A lei n: 3.807, de 26 de agosto de 1960 /LeiOrgânica da Previdência Sociall) diz, no seu art. 1․ , que a previdência social "tem por fim assegurar aos seus beneficiários os meios indispensáveis de manutenção, por motivo de idade avançada, incapacidade, tempo de serviço, prisão ou morte daqueles de quem dependiam economicamente, bem como a prestação de serviços que visem a proteção de sua saúde e concorram para o seu bem-estar". Por aí já se vê que a previdência social tem por escopo prestar serviços, e qualquer contribuição a ela destinada está vinculada à sua atuação no seu campo específico de atividade. $\mathrm{O}$ art. $2^{\circ}$ enumera as pessoas que se beneficiam da previdência, e que são: a. na qualidade de seguradas, todos os que exercem emprego ou atividade remunerada no território nacional, salvo as exceções expressamente consignadas; b. na qualidade de dependente, as pessoas definidas no artigo 11 lesposa, marido inválido, filhos inválidos ou menores de 18 anos, filhas solteiras quando inválidas ou menores de 21 anos, pai inválido e a mãe, irmão inválidos ou menores de 18 anos e irmãs solteiras, quando inválidas ou menores de 21 anos).

$\mathrm{O}$ art. $5^{\circ}$. determina a obrigatoriedade do seguro para: a. os que trabalham, como empregados, no território nacional; b. os brasileiros e estrangeiros domiciliados e contratados no Brasil, para trabalharem como empregados nas sucursais ou agências de empresas nacionais no exterior; c. os titulares de firma individual e diretores, sócios gerentes, sócios solidários, sócios quotistas, sócios de indústria, de qualquer natureza, cuja idade máxima seja, no ato da inscrição, de 50 anos; d. trabalhadores avulsos e autônomos.

$\mathrm{O}$ art. 69 define o sujeito passivo, estabelece a alíquota e base de cálculo, e, do seu correlacionamento com os artigos supramencionados, extrai-se o núcleo da hipótese de incidência. Com efeito, o referido artigo diz que o custeio da previdência social será atendido: a. pelos segurados em geral; b. pelos servidores das autarquias federais ( $\$ 11^{\circ}$, do art. 22); c. pelas empresas; d. pela União; e. pelos trabalhadores autônomos. Do elenco, só não são segurados da previdência (art. 5.) as empresas e a União.

Temos agora condições de descrever o núcleo das hipóteses de incidência das diversas normas que estabelecem a obrigação de contribuir para a previdência. Não descreveremos, entanto, a norma que estabelece tal obrigatoriedade para a União. É que aí, não estamos diante de uma norma tributária, mas de uma norma de direito financeiro, vale dizer, de direito administrativo, já que o direito financeiro não possui autonomia, quer científica lo que também ocorre com o direito tributário) quer didática. Limitar-nos-emos à descrição das normas tributárias.

Já vimos acima que a hipótese legal (hipótese de incidência, antecedente normativol consiste na previsão abstrata de um fato ou uma situação lauferir renda, industrializar produtos, ser proprietário de imóvel, importar mercadorias estrangeiras, possuir imóvel valorizado por obra pública, etc) - que podemos denominar núcleo - condicionado por coordenadas de tempo e espaço. O dado central é, por conseguinte, o núcleo, que no dizer de Geraldo Ataliba (Hipótese de incidência... p. 111) denomina-se aspecto material, sendo a própria descrição dos aspectos substanciais do fato ou conjunto de fa- 
tos que lhe servem de suporte". Para Paulo de Barros Carvalho (obra citada, p. 113 a 118) parece incorreta a tentativa de designar o núcleo da hipótese de incidência como a descrição objetiva do fato, uma vez que tal descrição pressupõe, invariavelmente, as circunstâncias de espaço e tempo que o condicionam. Assim fazendo estar-se-ia conceituando a própria hipótese ou antecedente normativo. Tal é certo, pois a descrição objetiva de um fato, envolvendo todos os seus aspectos substanciais, incluiria necessariamente as coordenadas de espaço e tempo. Como salienta o autor citado, "ao individualizar o critério material não se pode abarcar elementos estranhos que teriam o condão de emprestar-Ihe feição definitiva, como previsão de um evento". Propõe uma abstração absoluta dos demais critérios para que se possa extrair não o próprio fato, mas um outro evento que, uma vez condicionado no espaço e no tempo, se transforme no fato hipoteticamente descrito. "Dessa abstração - prossegue Paulo de Barros Carvalho - emerge sempre o encontro de expressões genéricas designativas de comportamentos de pessoas, sejam aqueles que encerrem um fazer, um dar ou, simplesmente, um ser (estado)". O citado autor nota que o núcleo da hipótese de incidência será formado, invariavelmente, por um verbo, seguido do seu complemento. Não sendo, desta forma, a descrição objetiva do fato ou acontecimento, pois tal éo arcabouço da própria hipótese. O núcleo da hipótese de incidência resumeSe, por conseguinte, no comportamento de uma pessoa (física ou jurídica), consistente num ser, num dar ou num fazer e obtido mediante processo de abstração no qual se desconsideram as coordenadas de espaço e tempo.

Pelas disposições, acima citadas, da lei orgânica da previdência social, verificamos que os núcleos são vários, o que nos leva a concluir estarmos diante de várias normas e, conseqüentemente, de vários tributos. Assim, infere-se do art. 69 , letra a, que temos como núcleo um ser: ser segurado da previdên$\mathrm{cia}$, definindo o artigo $5^{\circ}$, quais os segurados obrigatórios. O mesmo vale para a letra $b$, do art. 69 , cujos segurados estão referidos no $\S 1{ }^{\circ}$, do art. 22. Pela letra $c$, temos um outro núcleo. Este já não consistirá num ser, mas num fazer, vale dizer, remunerar segurados da previdência social. Pela letra $e$, verifica-se que o núcleo consiste num ser: ser trabalhador autônomo. Daí pode-se de pronto concluir que nos casos das letras $a, b$ e e estamos diante de tributos vinculados a uma atividade estatal, pos todos os Segurados (obrigatoriedade estabelecida pelo art. $5^{\circ}$ ) ) beneficiam-se da atividade estatal (art. $2^{\circ}$ ) diretamente referida ao contribuinte. Estamos, portanto, diante de taxa. No caso, no entanto, da letra $c$, o tributo não está vinculado a qualquer atividade estatal, pois as empresas não são seguradas da previ- dência (art. 5\%) nem beneficiárias (art. 2.). Estamos aí diante de um imposto (no mesmo sentido, veja-se Marco Aurélio Greco, A Chamada contribuição previdênciária, in RDP 19/385). Em conclusão, pela lei n. 3.807, de 26 de agosto de 1960, temos os seguintes núcleos de hipóteses de incidência de normas de contribuições previdenciárias; a) ser segurado da previdência; b) ser trabalhador autônomo; c) remunerar segurados da previdência. Os três núcleos de hipóteses de incidêhicia revelam a existência de três normas diferentes e, conseqüentemente, de três tributos diversos, como já foi anteriormente frisado

Definido o núcleo, vejamos, ainda sem considerar as modificações posteiores à Lei Orgânica, as coordenadas de espaço e tempo. A coordenação genérica de espaço será, obviamente, o território nacional. A competência para instituir tal tributo é da União (disposição constitucional), e, assim sendo, a coordenada genérica de espaço só poderá ser o território nacional, pois corresponden á área de competência territorial do sujeito ativo. Já a coordenada específica de espaço correlaciona-se logicamente com a área de atuação do sujeito passivo. Assim, para os segurados em geral (art. 68, a e b) e para as empresas (art. 68, letra c) a coordenada de espaço específica será o local da atividade, ou melhor, local onde se efetiva a remuneração, (sede da empresa, filial, sucursal, agência, escritório, etc) , o mesmo ocorrendo no caso dos trabalhadores autonômos. A coordenada de tempo é o período de trabalho efetivamente prestado (segurados) e o período mensal em que remunera (empregadores), consumando-se no primeiro dia do mês subseqüente. O prazo de recolhimento que corre no mês seguinte nada tem com a coordenada de tempo. Trata-se de um mero prazo de pagamento.

Vejamos agora o mandamento normativo. Como vimos, ele é composto pelas previsões objetivas (aliquotas e base de cálculo) e pelas previsões subjetivas (sujeito ativo e sujeito passivo). A base de cálculo está estabelecida pelo art. 69, combinado com o 76 da Lei Orgânica. Assim, para os segurados em geral a base de cálculo será o seu salário de contribuição, assim entendido a remuneração efetivamente percebida durante o período mensal lart. 76 , I). Para as empresas não há definição de base de cálculo, mas a fixação de uma quantia certa, correspondente a que for devida pelos segurados. Para os trabalhadores autônomos a base de cálculo é o salário-base (art. 76, III). As alíquotas estão fixadas na lei, salvo no caso das empresas, uma vez que, no caso de fixação certa do quantum debeatur, não há base de cálculo nem alíquota. As alíquotas e bases de cálculo a serem aplicadas serão sempre as vigentes na data de consumação da coordenada de tempo (aspecto temporal da hipótese de incidência). Cumpre-nos, finalmente, estabelecer os sujeitos ati- 
vo e passivo para, logo após, sintetizarmos a estrutura normativa das diversas normas, sempre com base na lei orgânica, para depois verificarmos a legislação posterior.

A União detém a competência tributárias para instituir e arrecadar os tributos previdenciários. Tanto no texto da Emenda n. ${ }^{\circ}$, como no da Emenda n. ${ }^{\circ}$ 8 , não se pode duvidar que a competência é da União. "Competência tributária é a aptidão para criar tributos, descrevendo legislativamente suas hipóteses de incidência... No Brasil, só as pessoas políticas (União, Estados e Municípios) detém a faculdade de produzir normas jurídicas tributárias (no nível legal)... "(Roque Antonio Carrazza, O Sujeito ativo da obrigação tributária, Editora Resenha Tributária, São Paulo, 1977, p. 28). No entanto, apesar de a União ser a titular da competência tributária, às autarquias que administram a previdência, que passam a ocupar o pólo ativo da relação jurídica que se instaura pela incidência do mandamento da norma. Os sujeitos passivos das diversas normas estão relacionados na lei, e já foram mencionados acima. São eles, os segurados em geral, os autônomos e as empresas. Isto colocado, podemos estruturar as diversas normas:

\section{Primeira norma}

Antecedente - a. núcleo: ser segurado da previdência; b. coordenada genérica de espaço: território nacional; c. coordenada específica de espaço: local de atividade do segurado; d. coordenada de tempo: período de trabalho efetivamente prestado.

Conseqüente - a. base de cálculo: salário de contribuição; b. alíquota: $6 \%$ a $8 \%$; c. sujeito ativo: autarquia previdenciária; d. sujeito passivo: o segurado.

\section{Segunda norma}

Antecedente - a. núcleo: ser trabalhador autônomo; b. coordenada genérica de espaço: território nacional; c. coordenada específica de espaço: local de atividade do autônomo (seu escritório); d. coordenada de tempo: período mensal de atividade.

Conseqüente - a. base de cálculo: saláriobase; b. alíquota: $6 \%$ a $8 \%$; c. sujeito ativo: autarquia previdenciária; d. sujeito passivo: o trabalhador autônomo.

\section{Terceira norma}

Antecedente - a. núcleo: remunerar segurados da previdência; b. coordenada genérica de es- paço: território nacional; c. coordenada específica de espaço: local onde ocorre a remuneração; $d$. coordenada de tempo: período mensal de remuneração.

Conseqüente - a. previsão objetiva (quantum debeatur): quantia idêntica à devida pelos segurados a seu serviço; b. sujeito ativo: autarquia previdenciária; sujeito passivo: a empresa remuneradora de segurados.

Nunca será demais frisar que as duas primeiras normas possuem o núcleo dos seus antecedentes (hipótese de incidência) vinculados à atividade estatal diretamente referida ao contribuinte, enquanto que a terceira possui tal núcleo desvinculado de qualquer atividade estatal. As duas primeiras configuram taxas e a terceira, imposto.

Um dos aspectos da primeira norma deve ainda ser analisado. Trata-se do sujeito passivo, isto éo segurado, parte do mandamento da norma, referido no complemento do núcleo da hipótese de incidência. O art. 50. da Lei Orgânica enumera experessamente que são obrigatoriamente segurados, a saber: I - os que trabalham, como empregados, no território nacional, II - os brasileiros e estrangeiros domiciliados e contratados no Brasil, para trabalharem como empregados nas sucursais ou agências de empresas nacionais no exterior; III - os titulares de firma individual e diretores, sócios gerentes, sócios solidários, sócios quotistas, sócios de indústria, de qualquer empresa, cuja idade máxima seja no ato da inscrição de cinqüenta anos. O inciso IV explicita o trabalhador autônomo, mas como este compõe a estrutura de outra norma deve ser posto de lado, uma vez que só estamos analisando a primeira norma acima mencionada. Como o art. 2\% , inciso I, afirma serem beneficiários da previdência, na qualidade de segurados, todos os que exercem emprego ou atividade remunerada no território nacional, e o artigo $5^{\circ}$ explicita, como vimos, os que são obrigatoriamente segurados, dá margem a que se infira a existência de segurados facultativos, o que sugere a possibilidade de tributo sem obrigação. Esta tese não é tão estranha quanto à primeira vista possa parecer, pois já foi cogitada por juristas de escol (Antônio Berliri, Princípios de derecho tributário, vol. I, tradução espanhola por Fernando Vicente-Arche Domingo, Editorial de derecho financeiro, Madrid, 1964, p. 307 a 320 e 432 a 469; Marco Aurélio Grego, Breves consideraçőes sobre a possibilidade de haver tributo sem obrigação, in RDP 22/341).

Pelas disposições da Lei Orgânica só serão obrigatoriamente segurados, e, como tais, sujeitos passivos da taxa descrita no item acima, e que denominamos 1 . norma, os empregados los itens l e ll do art. $5^{\circ}$ ) e os titulares de firma individual, diretores, 
sócios gerentes, sócios solidários, sócios quotistas, sócios de indústria, de qualquer empresa, cuja idade no momento da inscrição, seja inferior a 50 anos.

Com o advento do decreto-lei n? 66, de 21 de novembro de 1966, modificaram-se disposições da Lei Orgânica (lei n: 3.807, de 26 de agosto de 1960). Tal decreto-lei alterou aspectos normativos dos tributos ora em exame, modificando a redação do art. 69. Assim, a primeira norma, esquematizada no inciso 5.9 , passa a ter a alíquota de $8 \%$ (oito por cento) ficando a base de cálculo limitada a dez vezes o maior salário-mínimo vigente. A nova redação não enumerou os trabalhadores autônomos, mas estes não perderam a condição de segurados obrigatórios, pois não houve modificação no caput do art. $5^{\circ}$ da tei n: 3.807. Para efeito da nova redação do art. 69 , os autônomos passaram a integrar a categoria de segurados em geral. As bases de cálculo das duas primeiras normas, esquematizadas no inciso 5.9 , foram identificadas sob a denominação genérica de salário-contribuição, sendo o salário-base uma espécie deste último, aplicado aos autônomos. As duas primeiras normas só não podem ser totalmente identificadas por dois aspectos que as distinguem, ainda que se pretenda incluir o trabalhador autônomo na categoria genérica de segurados em geral: em primeiro lugar, são distintas as coordenadas de tempo, pois enquanto para os empregados em geral, diretores, gerentes, etc., ela continua sendo o período efetivamente trabalhado, podendo ser inferior a um mês, para os autônomos ela coincide sempre com o período mensal. No caso dos empregados o tempo de um mês refere-se ao período de cobrança, porque o salário é pago mensalmente, mas a coordenada de tempo é o período de trabalho efetivamente prestado. A segunda distinção é a base de cálculo, pois enquanto no caso da primeira norma, que prevê a incidência do tributo sobre os segurados em geral, a base de cálculo é a remuneração efetivamente percebida (art. 19, do decreto-lei n. 66 , que alterou o art. 76 da Lei Orgânica), no caso da segunda, que prevê a incidência sobre os autônomos, a base de cálculo é o sálario-base. Se bem que, pela sistemática do decreto-lei n. 66, o salário-base e a remuneração efetivamente percebida pertençam a um gênero comum, qual seja o salário-contribuição, são espécies distintas deste mesmo gênero, o que impede a redução das duas primeiras normas em uma única. A própria diferença entre as bases de cálculo serve para demonstrar a diferença entre as coordenadas de tempo. Já sabemos que entre todas as previsões normativas, estejam elas no antecedente (hipótese de incidência) ou no conseqüente (mandamento), deve haver um correlacionamento lógico. Ora, se a base de cálculo da primeira norma cão efetivamente percebida, a coordenada de tem- po, logicamente correlacionada, será o período de trabalho efetivamente prestado, o fator que diz respeito a pagamento do tributo, integra a norma individual do lançamento, e não a norma geral do tributo, que prevê o nascimento da obrigação tributária.

Nova alteração na Lei Orgânica da Previdência é feita pela lei n. 5.890, de 8 de junho de 1973. O art. $5 \%$, que enumera os segurados obrigatórios foi alterado. No inciso III, que relaciona os titulares de firmas individuais, diretores, sócios gerentes, etc.... retirou-se a limitação máxima de idade, e, no inciso IV, suprimiu-se a categoria trabalhador avulso. O art. 69 da Lei Orgânica teve também sua redação alterada. Pela nova redação, além de modificações nas alíquotas e bases de cálculo, foram ampliadas as previsões normativas, e com elas, obviamente, o número de normas, que não podem mais ser reduzidas a três, conforme esquema do inciso 5.9. Está assim redigida a nova redação do art. 69:

"O custeio da previdência social será atendido pelas contribuições:

I - dos segurados, em geral, na base de $8 \%$ (oito por cento) do respectivo salário-de-contribuição, nele integrada todas as importâncias recebidas a qualquer título;

II - dos segurados de que trata o $\S 2^{\circ}$. do artigo 22 , em percentagem do respectivo vencimento igual à que vigorar para o Instituto de Previdência e Assistência dos Servidores do Estado, com o acréscimo de $1 \%$ (um por cento) para o custeio dos demais benefícios a que fazem jus, e de $2 \%$ (dois por centol para a assistência patronal;

III - das empresas, em quantia igual à que for devida pelos segurados a seu serviço, inclusive os de que trata o item III do art. $5^{\circ}$, obedecida quanto aos autônomos a regra a eles pertinente;

IV - da União, em quantia destinada a custear o pagamento de pessoal e as despesas de administração geral da previdência social, bem como a de cobrir as insuficiências financeiras verificadas;

$V$ - dos autônomos, dos segurados facultativos e dos que se encontram na situação do art. 9? na base de 16 (dezesseis por cento) do respectivo salário de contribuição, observadas quanto a este as normas do item I deste artigo;

VI - dos aposentados, na base de $5 \%$ (cinco por centol do valor dos respectivos benefícios;

VII - dos que estão em gozo de auxílio-doença, na base de $2 \%$ (dois por cento) dos respectivos benefícios.

Parágrafo primeiro - A empresa que se utilizar de serviços de trabalhador autônomo fica obrigada a reembolsá-lo, por ocasião do respectivo pa- 
gamento, no valor correspondente a $8 \%$ (oito por cento) da retribuição a ele devida até o limite do seu salário-de-contribuição, de acordo com as normas previstas no item I deste artigo.

Parágro segundo - Caso a remuneração paga seja superior ao valor do salário-de-contribuição, fica a empresa obrigada a recolher ao Instituto $\mathrm{Na}$ cional de Previdência Social a contribuição de $8 \%$ (oito por cento) sobre a diferença entre aqueles dois valores.

Parágrafo terceiro - Na hipótese da prestação de serviços de trabalhador autônomo a uma só empresa, mais de uma vez, durante o mesmo mês, correspondendo assim a várias faturas ou recibos, deverá a empresa entregar ao segurado apenas o valor correspondente a $8 \%$ (oito por cento) do seu salário contribuição, uma só vez. A contribuição de $8 \%$ (oito por cento) correspondente ao excesso será recolhida integralmente ao Instituto Nacional de Previdência Social pela empresa.

Parágrafo quarto - Sobre o valor da remuneração de que tratam os parágrafos anteriores não será devida nenhuma outra das contribuicões arreca. dadas pelo Instituto Nacional de Previdência Social.

Parágrafo quinto - Equipara-se a empresa, para fins de previdência social, o trabalhador autốnomo que remunerar serviços a ele prestados por outro trabalhador autônomo, bem como a cooperativa de trabalho e a sociedade civil, de direito e de fa. to, prestadora de serviços".

Pelas alterações da lei no 5.890 , temos as seguintes estruturas normativas:

\section{Primeira norma}

Antecedentes - a. núcleo: ser segurado da previdência; $b$. coordenada genérica de espaço: território nacional; c. coordenada específica de espaco: local de atividade do segurado; d. coordenada de tempo: periodo de trabalho efetivamente prestado.

Conseqüente $-\mathrm{a}$. base de cálculo: a remuneração efetivamente percebida; b. a alíquota: $8 \%$; c. sujeito ativo: a autarquia presidenciária; d. sujeito passivo: o segurado lempregados no território nacional; brasileiros e estrangeiros domiciliados e contratados no Brasil para trabalharem como empregados nas sucursais ou agências de empresas nacionais no exterior; titulares de firmas individuais, diretores, sócios-gerentes, sócios solidários, sócios quotistas, sócios de indústria).

\section{Segunda norma}

Antecedente - a. núcleo: ser servidor estatu- tário de autarquia previdenciária; $b$. coordenada genérica de espaço: território nacional; c. coordenada específica de espaço: local de atividade do servidor previdenciário; $d$. coordenada de tempo: período de trabalho efetivamente prestado.

Conseqüente - a. quantum debeatur: quantia idêntica à devida para a Previdência dos Servidores do Estado, com o acréscimo de $3 \%$; b. sujeito ativo: a autarquia previdenciária; c. sujeito passivo: servidor estatutário de autarquia previdenciária.

\section{Terceira norma}

Antecedente - a. núcleo: remunerar segurados da previdência social; $b$. coordenada genéria de espaço: território nacional; c. coordenada específica de espaço: local onde ocorre a remuneração; d. coordenada de tempo: período mensal de remuneração.

Conseqüente - a. quantum debeatur: quantia idêntica à que for devida pelos segurados a seu serviço (inclusive os diretores, sócios gerentes, titular de firma individual, bem como os autônomos); $b$. sujeito ativo: autarquia previdenciária; c. sujeito passivo: a empresa remuneradora dos segurados.

\section{Quarta norma}

Antecedente - a. núcleo: ser trabalhador autônomo; b. coordenada genérica de espaço: território nacional; c. coordenada específica de espaço: Iocal de atividade do autônomo (seu escritório); d. coordenada de tempo: período mensal de atividade.

Conseqüente - a. base de cálculo: salário base; b. alíquota: $16 \%$; c. sujeito ativo: autarquia previdenciária; d. sujeito passivo: trabalhador autônomo.

\section{Quinta norma}

Antecedente - a. núcleo: ser segurado facultativo; b. coordenada genérica de espaço: território nacional; c. coordenada específica de espaço: domicílio do segurado; d. coordenada de tempo: período mensal.

Conseqüente - a. base de cálculo: salário base; b. alíquota: $16 \%$; c. sujeito ativo: autarquia previdenciária; d. sujeito passivo: segurado facultativo.

\section{Sexta norma}

Antedente - a. núcleo: ser aposentado pela previdência; $b$. coordenada genérica de espaço: território nacional; c. coordenada específica de espa- 
ço: domicílio do aposentado; d. coordenada de tempo: período mensal.

Conseqüente - a. base de cálculo: valor do benefício percebido; b. alíquota: $5 \%$; c. sujeito ativo: aposentado.

\section{Sétima norma}

Antecedente - a. núcleo: estar em gozo de auxilio-doença; b. coordenada genérica de espaço: território nacional; c. coordenada específica de espaço: local de atividade interrompida; d. coordenada de tempo: período de duração do auxílio doença.

Conseqüente $-a$. base de cálculo: benefício percebido; b. alíquota: $28 \%$; c. sujeito ativo: autarquia previdenciária; d. sujeito-passivo: quem percebe o auxílio-doença.

\section{Oitava norma}

Antecedente - a. núcleo: ser pensionista da previdência; $b$. coordenada genérica de espaço: território nacional; c. coordenada específica de espaco: domício do pensionista; $d$. coordenada de tempo: período mensal.

Conseqüente - $\mathrm{a}$. base de cálculo: benefício percebido; b. alíquota: $2 \%$; c. sujeito ativo: autarquia previdenciária; $d$. sujeito passivo: o pensionis-
ta.

Pode-se verificar, desde logo, que apenas a terceira norma tem o núcleo de seu antecedente normativo desvinculado de qualquer atividade estatal. Configura portanto um 'imposto', ao contrário das demais que são 'taxas'. Alguns comentários tornam-se ainda necessários aos dispositivo transCrito no inciso 5.14. É que havendo, no $\S 1 \%$, obrigatoriedade de a empresa que se utiliza de serviços de autônomo, de reembolsá-lo em $8 \%$ (oito por cento) da retribuição a ele devida, até o limite do seu salário-de-contribuição, poderia parecer que a alíquota da 4. norma seria $8 \%$ (oito por cento), e não 16\% (dezesseis por cento). Acontece que a obrigação da empresa para com o trabalhador autônomo não configura a mesma obrigação, e só surge como conSeqüência da obrigação tributária que se estabelece entre o autônomo e a previdência, em decorrência da incidência da quarta norma, acima esquematizada. A obrigação do reembolso é, necessária e cronologicamente, posterior ao surgimento da obrigação tributária do autônomo. A definição da sua natureza foge aos limites da consulta, mas a sua estrutura normativa é a seguinte: Antecedente - a. núcleo: remunerar traba-
Ihador autônomo; b. coordenada genérica de espa- ço: local de atividade do autônomo; c. coordenada específica de espaço: local de atividade da empresa remuneradora; d. coordenada de tempo: período mensal.

Conseqüente - a. base de cálculo: retribuição devida pelos serviços até o limite do salário-decontribuição; b. alíquota: $8 \%$ c. sujeito ativo: o trabalhador autônomo; d. sujeito passivo: a empresa remuneradora.

Resta-nos agora examinar as disposições da Consolidação dạs Leis da Previdência Social. Tal diploma, embora expedido por Decreto, disposição do art. $6^{\circ}$, da lei $n^{\circ}$. 6.243 , de 24 de setembro de 1975, não modificou a matéria legal substantiva. Assim, a referida Consolidação, baixada pelo Decreto n: 77.077, de 24 de janeiro de 1976, não é regulamento, porém mera ordenação de disposições legais. O texto, no seu art. $5^{\circ}$, define como segurado obrigatório: "I - o que trabalha como empregado no território nacional; II - o brasileiro ou o estrangeiro domiciliado no Brasil e aqui contratado para trabalhar como empregado em sucursal ou agência de empresa nacional no exterior; III - o titular de firma individual e o diretor, sócio gerente, sócio solidário, sócio cotista e sócio de indústria, de qualquer empresa; IV - o trabalhador autônomo."

Os parágrafos do referido artigo dão algumas explicações que podem ter utilidade para definições de algumas estruturas normativas. São eles: "§ 1 ? - O empregado de representação estrangeira e o de organismo oficial estrangeiro ou internacional que funcione no Brasil são equiparados aos trabaIhadores autônomos, salvo se obrigatoriamente sujeitos a regime próprio de previdência. $\S 3^{\circ}$ - O diretor, sócio gerente, sócio solidário, sócio cotista que receba pro labore e sócio-de-indústria de empresa de natureza agrária ou que preste serviços dessa natureza são segurados obrigatórios do I.N.P.S. a contar de $1^{\circ}$. de janeiro de 1976.

O art. 128 refere-se ao custeio da previdência, especificando alíquotas e bases de cálculo. Pela redação do artigo, o custeio da previdência social será atendido pelas seguintes contribuições: "I - dos segurados em geral, de $8 \%$ (oito por cento) do respectivo salário-de-contribuição, nele integradas todas as importâncias recebidas a qualquer título; II o empregado doméstico, de $8 \%$ (oito por cento) do valor do salário-mínimo regional; III - do segurado facultativo, do que se encontra na situação do art. 11 e.do autônomo, exceto o trabalhador avulso (art. $7^{\circ}$ ), de $16 \%$ (dezesseis por cento) do respectivo salário-de-contribuição; IV - do auxiliar de condutor autônomo de veículo rodoviário, igual à do condutor autônomo de veículo rodoviário (item III); V - do servidor estatutário de I.N.P.S., de percentagem do 
respectıvo vencimento igual à que vigorar para o lnstituto de Previdência e Assistência dos demais benefícios a que faz jus e de $2 \%$ (dois por cento) para a assistência patronal; VI - da empresa em geral; a) de quantia igual à devida pelos segurados a seu serviço, inclusive os do item III e \&\& $3^{\circ}$ a $5^{\circ}$. do artigo e os do artigo $7{ }^{\circ}$, obedecidas quanto aos demais autonômos as disposições pertinentes; b) de mais 1,2\% (um e dois décimos por cento) da folha de saláriosde-contribuição dos seus empregados e dos trabaIhadores avulsos que the prestem serviços, compreendendo sua própria contribuição e a desses segurados, para custeio do abono anual; c) de $4 \%$ (quatro por cento) da folha de salários-de-contribuição dos seus empregados e dos trabalhadores avulsos que lhe prestem serviços, para custeio do salário família; d) de $0,3 \%$ (três décimos por cento) da folha de salários-de-contribuição, para custeio do saláriomaternidade; VII - do empregador doméstico, de quantia igual à que for devida pelos empregados domésticos a seu serviço; VIII - da União, de quantia destinada a custear o pagamento do pessoal e demais despesas de administração geral do I.N.P.S., bem como, se for o caso, a cobrir as insuficiências financeiras verificadas".

Pela redação dos dispositivos acima, temos as seguintes estruturas normativas:

\section{Primeira norma}

Antecedente: a. núcleo: ser segurado da previdência; b. coordenada genérica de espaço: território nacional; c. coordenada específica de espaço: local de atividade do segurado; d. coordenada de tempo: periodo de trabalho efetivamente prestado.

Conseqüente: a. base de cálculo: remuneração efetivamente percebida (art. 138. I); b. aliquota: $8 \%$ (oito por cento); c. sujeito ativo: autarquia previdenciária; d. sujeito passivo: o segurado lempregados no território nacional; brasileiros e estrangeiros domiciliados e contratados no Brasil para trabalhar como empregado em sucursal ou agência de empresa nacional no exterior; titulares de firmas individuais; diretores, sócios gerentes, sócios solidários, sócios quotistas, sócios de indústrias). (Note-se que o núcleo, e portanto esta norma, pode ser desdobrada em tantas quantos são os segurados.)

\section{Segunda norma}

Antecedente: a. núcleo: ser empregado doméstico; b. coordenada genérica de espaço: território nacional; c. coordenada específica de espaço: residência do empregador doméstico (local de atividade do empregadol; d. coordenada de tempo: período de trabalho efetivamente prestado.
Conseqüente: a. base de cálculo: saláriomínimo regional; b. alíquota: $8 \%$ (oito por cento); c. sujeito ativo: autarquia previdenciária; d. sujeito passivo: o empregado doméstico. 10 fundamento desta norma extraída da Consolidação é a lei $n$. 5.859, de 11 de dezembro de 1972.)

\section{Terceira norma}

Antecedente: a. núcleo: ser segurado facultativo; b. coordenada genérica de espaço: território nacional; c. coordenada específica de espaço: domicílio do segurado facultativo; $d$. coordenada de tempo: período mensal.

Conseqüente: a. base de cálculo: salário de contribuição; b. alíquota: 16 (dezesseis por cento); c. sujeito ativo: autarquia previdenciária; d. sujeito passivo: o segurado facultativo.

\section{Quarta norma}

Antecedente: a. núcleo: ser trabalhador autônomo; b. coordenada genérica de espaço: território nacional; c. coordenada específica de espaço: local de atividade do trabalhador autônomo; d. coordenada de tempo: período mensal.

Conseqüente: a. base de cálculo: salário base; b. alíquota: $16 \%$ (dezesseis por cento); c. sujeito ativo: autarquia previdenciária; d. sujeito passivo: o trabalhador autônomo.

\section{Quinta norma}

Antecedente: a. núcleo: ser trabalhador avulso; b. coordenada genérica de espaço: território; c. coordenada específica de espaço: domicílio do trabalhador avulso; d. coordenada de tempo: período mensal.

Conseqüente: a. base de cálculo: a vigente em 11 de junho de 1973 (art. 7.); b. aliquota; idem; c. sujeito ativo: autarquia previdenciária; d. sujeito passivo: o trabalhador avulso.

\section{Sexta norma}

Antecendente: a. núcleo: ser auxiliar de condutor autônomo de veículo rodoviário; b. coordenada genérica de espaço: território nacional; d. coordenada específica de espaço: domicílio do auxiliar de condutor autônomo de veículo; coordenada de tempo; período mensal.

Conseqüente: a. base de cálculo: salário base; b. alíquota: $16 \%$ (dezesseis por cento); c) sujeito ativo: autarquia previdenciária; d. sujeito passivo: auxiliar de condutor autônomo de veículo rodoviário. 
10 fundamento desta norma extraída da Consolidação é a lei n: 6.094, de 30 de agosto de 1974.)

\section{Sétima norma}

Antecedente: a. núcleo; ser servidor estatutário do I.N.P.S.; b. coordenada genérica de espaço: território nacional; c. coordenada específica de espaço: repartição onde o servidor estiver lotado; d. coordenada de tempo: período de serviço efetivamente prestado.

Conseqüente: a. base de cálculo: vencimento percebido; b. alíquota: a que vigorar para o IPASE, acrescida de $1 \%$ (um por cento) e mais $2 \%$ (dois por cento); d. sujeito ativo: autarquia previdenciária; $d$. sujeito passivo: servidor estatutário do I.N.P.S.

\section{Oitava norma}

Antecendente: a. núcleo: remunerar segurados da previdência isejam eles empregados, autônomos, titular de firma individual, diretor, sócio sócio gerente, sócio solidário, sócio quotista, sócio de indústria, de empresas industriais, comerciais, civis ou agrárias, ou ainda aposentados); b. coordenada genérica de espaço: território nacional; c. coordenada específica de espaço: estabelecimento do remunerador (seja matriz, filial, sucursal, agência, escritório); d. coordenada de tempo: período mensal de remuneração.

Conseqüente: a. quantum debeatur: quantia idêntiCa à que for devida pelos segurados a seu serviço; $b$. Sujeito ativo: autarquia previdenciária; c. sujeito passivo: o remunerador.

\section{Nona norma}

Antecendente: a. núcleo: remunerar segurados da previdência; b. coordenada genérica de espaço: território nacional; c. coordenada específica de espaco: estabelecimento do remunerador; $d$. coordenada de tempo: período mensal de remuneração.

Conseqüente: a. base de cálculo: salários-decontribuição dos empregados e avulsos, mais a contribuição do remunerador, dos empregados e dos avulsos; b. alíquotas: 1,2\% (um e dois décimos por cento); c. sujeito ativo: autarquia previdenciária; $d$. sujeito passivo: o remunerador de segurados. (Esta norma é tributo adicional da oitava norma.)

\section{Décima norma}

Antecendente: a. núcleo: remunerar segura-
dos da previdência; b. coordenada genérica de esPaço: território nacional; c. coordenada específica de espaço: estabelecimento do remunerador; $d$ coordenada de tempo: período de remuneração.

Conseqüente: a. base de cálculo: salário de contribuição dos seus empregados e trabalhadores avulsos; b. alíquota: $4 \%$ (quatro por cento); c. sujeito ativo: autarquia previdenciária; $d$ d. sujeito passivo: o remunerador de segurados. (Esta norma é tributo adicional da oitava norma.)

\section{Décima primeira norma}

Antecedente: a. núcleo: remunerar segurados da previdência; b. coordenada genérica de espaço: território nacional; c. coordenada específica de espaço: estabelecimento do remunerador; $d$. coordenada de tempo: período mensal de remuneração.

Conseqüente: a. base de cálculo: salário de contribuição dos empregados; b. alíquota: 0,3\% (três décimos por cento); c. sujeito ativos: autarquia previdênciária; d. sujeito passivo: o remunerador de segurados. (Esta norma é tributo adicional da oitava norma.)

\section{Décima segunda norma}

Antecendente: a. núcleo: remunerar empregado doméstico; b. coordenada genérica de espaço: território nacional; c. coordenada específica de espaço: residência do empregador (remunerador): d. coordenada de tempo: período efetivo de remuneração.

Conseqüente: a. quantum debeatur: quantia igual à que for devida pelo empregado; $b$. sujeito ativo: autarquia previdenciária; c. sujeito passivo: o remunerador de empregado doméstico.

Temos assim doze normas, que podem ser desdobradas em dezenas. Algumas explicaçð̋es tornam-se entanto necessárias. A primeira dúvida que poderá de pronto surgir é o fato de termos incluído os acréscimos de $1 \%$ (um por cento) e $2 \%$ (dois por cento) previstos no inciso V do art. 128, Transcrito em 5.19, como integrantes da alíquota da sétima norma, e os acréscimos do inciso VI como integrantes de normas adicionais. Tanto os acréscimos do inciso $V$ como os das letras b, ce d, do inciso $\mathrm{VI}$, representam acréscimos com destinação especifica, mas, como é sabido, a destinação que se dá ao produto da arrecadação não compõe a estrutura da norma tributária, sendo disposição de direito administrativo ou financeiro. Neste particular, os acréscimos são idênticos. O que distingue os acréscimos do inciso $V$ dos acréscimos do inciso VI é que, enquanto os acréscimos previstos no inciso $V$ incidem sobre a mesma base de cálculo da alíquota principal, isto é, o vencimento do servidor estatutário, os 
acréscimos do inciso VI (letras b, c e d) incidem sobre bases de cálculo diversas do quantum debeatur previsto na alínea a do mesmo artigo. Não se trata, portanto, de simples acréscimo de alíquota para cobrir despesas específicas, mas de verdadeiras impostos adicionais, pois a diversidade das bases de cálculo distingue tipos tributários. A segunda observação a ser feita é que, enquanto a primeira, a segunda, a terceira, a quarta, a quinta, a sexta e a sétima normas são tributos vinculados, cuja atividade estatal está diretamente referida ao contribuinte (sujeito passivol, sendo portanto 'taxas', a oitava, a nona, a décima, a décima-primeira e a décimasegunda normas são tributos desvinculados que qualquer atividade do Estado sendo, por consequinte, 'impostos'. A última consideração a fazer éno tocante às bases de cálculo, previtas nas letras b, $c$ ed, do inciso VI, e que figuram nas esquematizações da nona, da décima e da décima primeira normas. A dúvida prende-se à base de cálculo da décima primeira normas, que traduzimos, no esquema acima, como sendo o salário-de-contribuição dos empregados, excluindo o salário-de-contribuição dos avulsos, bem como os demais componentes da base de cálculo da nona norma. Mas, se a lei nas letras $b$ e $c$ adicionou à base de cálculo algo além da folha de salário-de-contribuição dos empregados, e, na letra $d$, nada adicionou, significa que, neste último caso, a base de cálculo é, tão-somente, a folha de contribuição dos empregados. Quando o texto legal faz uma enumeração, e logo abaixo exclui algo previsto na enumeração acima, significa que o que foi
excluído abaixo só pode ser incluído acima

Desde a Lei Orgânica até a Consolidação, as contribuições previdenciárias tiveram as estruturas normativas acima descritas, traduzindo-se ora em
impostos, ora em taxas.

\section{As Limitações constituicionais ao poder de tributar.}

Dizer que as contribuições previdenciárias são tributos significa dizer que estão elas sujeitas ao regite, no caso a Uniåo, está sujeito, o poder tributanda Carta Magna.

O princípio basilar de todo o regime jurídico tributário, consagrado constitucionalmente, é o da legalidade, expresso, de forma específica, nos arts. 19, item 1, e 153, § 29. Até a Emenda Constitucional
$n^{\circ}$ 8, de 14 de abril de 1977 , as contribuicõos denciárias poderiam ter suas alíquotrições previcálculo alteradas pelo Poder Executivo. estavam referidos no item I, do $\$ 2^{\circ}$. Tais tributos Carta Magna, que, por sua vez, repo, do art. 21 , da I, do art. 21, o qual, fazendo pequena-se ao inciso princípio da legalidade, faculta ao Poder Executivo, nos limites e condições estabelecidos em lei, alterarIhe as alíquotas ou as base de cálculo. Hoje, previstos que estão no inciso $X$, do art. 43 , que não faz a mesma ressalva, o Poder já não desfruta da mesma faculdade. Estão, portanto, tais tributos, inteiramente submetidos ao princípio da legalidade. Tal fato já foi observado pelo Ministro Carlos Mário. Velloso (voto referido anteriormente neste parecer) que acentuou, com sabedoria, que não se legisla impunemente. Pois hoje, mesmo que alguém por igno rância - pois só a ignorância justifica tal pensamento - não considerar tais contribuições tributos, não poderá deixar de vê-las como obrigações, e, portanto, ainda que não tributárias, sujeitas ao princípio da legalidade expresso no $\$ 2$ ? , do art. 153.

Outro princípio a que estão subordinados tais tributos, é o da anterioridade, consagrado na parte final do $\$ 29$, do art. 153, do Texto Maior, que dispõe que nenhum tributo será "... cobrado em cada exercicio, sem que a lei que o houver instituído ou aumentado esteja em vigor antes do início do exercicio trananceiro, ressalvados a tarifa aduaneira e a de transporte, o imposto sobre produtos industrializados e outros especialmente indicados em lei complementar, além do imposto lançado por motivo de Constituicã demais casos previstos nesta mas o certo é que não há hade da redação é notória, buicões previdenciárias, qualquer ressalva às contricrito, nem em qualquer outro no dispositivo transem qualquer lei complement da Constituição, nem

Outro princípio a ser acatado pela legislação que instituir tal tributo é o da isonomia lart. 153, § 19 ), bem como o seu corolário, inscrito no inciso $I$, do art. 20, que veda à União "instituir tributo que não seja uniforme em todo o território nacional ou implique distinção ou preferência em relação a qualquer Estado ou Município em prejuízo de outro" Mas não é só, pois as normas classificadas como impostos não poderão ser exigidas de Estados, Municípios e suas respectivas autarquias, em decorrência do princípio da imunidade tributária recíproca lart. 19, III, a, da Constituição), nem de templos de qualquer culto (art. 19, III, b), nem de partidos políticos (art. 19, III, c), nem de instituiç̋̃es de educação ou de assistência social que observem os requisitos da
lei (art. 19, III, c). ciárias'.

Tais são os limites às 'contribuições previden-

\section{O Decreto n.o 83.081, de 24 de janeiro de 1979, e a lei n. 6.887 , de 10 de dezembro de 1980.}

Sob a égide da inconstitucionalidade e da ile- 
galidade adveio o Decreto n: 83.081, de 24 de janeiro de 1979. Isto porque criou como núcleo de hipótese de incidência a previsão do fato de ser membro de conselho de administração de sociedade anôni$\mathrm{ma}$, incluindo esta categoria entre os segurados obrigatórios. Já fizemos notar acima, mais precisamente no esquema da primeira norma, no inciso 5.20 , que tal norma poderia ser desdobrada em tantas quantas são os segurados obrigatórios. Assim, teríamos diversas normas com os seguintes núcleos de suas hipóteses de incidência: ser segurado no território nacional; ser empregado, contratado no Brasil, em sucursal ou agência, de empresa nacional, no exterior; ser titular de firma individual; ser diretor de companhia; ser sócio gerente de sociedade por quotas de responsabilidade limitada, etc. (vide primeira norma, inciso 5.20). Se o Decreto acima referido criou nova hipótese de incidência, inovou a lei, sendo ilegal, e como só a lei pode criar ou alterar tributos, afrontou a Carta Magna que, como vimos, consagrou o princípio da legalidade. Não poderia portanto a autarquia previdenciária exigir qualquer contribuição dos membros do conselho de administração de uma companhia.

Não satisfeito, o Poder Executivo, em praticar uma inconstitucionalidade, resolveu repeti-la com a portaria do Secretário de Previdência Social n: 2, de 6 de junho de 1979, publicada no Diário Oficial da União, de 11 de julho. Tal portaria volta a relacionar (letrai, do item 2) os membros do conselho de administração de uma companhia entre os segurados obrigatórios sem qualquer autorização legal. Sendo inconstitucionais, nem o Decreto nem a portaria devem, neste aspecto, ser obedecidos, pois a obediência a estes textos menores significaria desobediência à lei e à Constituição.

Não se poderá jamais alegar que os membros do conselho de administração já estavam incluídos entre os segurados, por analogia 'a diretores'. Tal afirmação seria verdadeiro despautério jurídico. Em primeiro lugar, a lei $n$ ? 6.404, de 15 de dezembro de 1976, destingue nitidamente os dois órgãos, pois o art. 138 afirma que "a administração da companhia competirá, conforme dispuser o estatuto, ao consetho de administração e à diretoria, ou somente à diretoria", empregando a aditiva e que revela conceitos diversos (pois não se adicionam conceitos idênticos). Por outro lado, o mesmo artigo demonstra a possibilidade de não haver conselho de administra- ção, o que não ocorre com a diretoria, o que é novo fator de distinção. $0 \S 11^{\circ}$, do mesmo artigo, define o conselho de administração como órgão de deliberação coletiva, não representativo da companhia, atividade privativa da diretoria, eo $\$ 2^{\circ}$. determina quais os tipos de companhia que terão obrigatoriamente conselho de administração. Não há, assim, entre os dois conceitos (conselho de administração e direto-

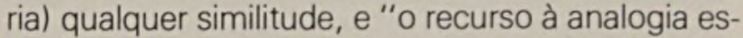
tende... um preceito de lei a casos nele não compreendidos, mas que tenham, com as hipóteses de incidência previstas na lei, uma relação de afinidade que os coloca na mesma razão jurídica que inspirou as hipóteses da norma em questão" (Américo Masset Lacombe, Considerações sobre o raciocínio juridico, in RDP 24/47). O recurso ao processo analógico só será portanto legítimo se ocorrer comunidade de elementos jurídicos a serem tomados em consideração. Será assim necessário que a hipótese, à qual se pretenda estender a lei, apresente caracteres jurídicos análogos àqueles da hipótese expressamente regulada (idem). Ora, no caso tal não ocorre. $\mathrm{O}$ único ponto comum é o fato de serem órgãos de sociedade anônima, mas a própria legislação previdenciária não aceitou tal semelhança, pois, como vimos acima, sempre distinguiu os diversos tipos de cargos e tipos de participação societária destacando inclusive os sócios-gerentes dos sócios quotistas, quando se sabe que o sócio gerente deve necessariamente ser sócio quotista numa sociedade por quotas de responsabilidade limitada. Em segundo lugar, o § 10., do art. 108, do Código Tributário Nacional é expresso ao determinar que o "emprego da analogia não poderá resultar na exigência de tributo não previsto em lei" . Ora, a pretensão de cobrar, por analogia, a contribuição previdenciária dos membros dos conselhos de administração de uma sociedade anônima, resultaria exatamente na exigência de tributo não previsto em lei.

Tanto os órgãos previdenciários sentiram a deficiência do Decreto e da portaria acima referidas, que adveio a Lei 6.887, de 10 de dezembro de 1980. Esta lei incluiu os membros dos conselhos de administração de sociedades anônimas entre os segurados obrigatórios da previdência, fazendo alterações no art. 5. e no art. 69 , da lei 3.807 , com suas modificações posteriores. Tal lei, em decorrência do princípio da anterioridade, acima explicado, só poderá ser aplicada a partir de 1. de janeiro de 1981, o que o próprio legislador verificou, ao dizer no art. $4^{\circ}$, que a lei entra em vigor na data inicial do exercício. 